\title{
THE INFLUENCE OF TRAINING AND CAREER DEVELOPMENT ON EMPLOYEE JOB SATISFACTION
}

\author{
Firgan Mulyadi \\ Universitas Langlangbuana, Indonesia \\ firdausfirganmulyadi@gmail.com
}

\begin{abstract}
A high target has always been the orientation of almost all companies because it will make the company progress and develop, so the company must create employee job satisfaction so that the employee can work optimally and accelerate what is the company's orientation. Career Training and Development is an important factor of course within the company because it is a motivating factor for employees to be able to make the company progress and develop. This research aims to assist PT Kartika Inti Sejati in realizing its future desires in achieving its vision and mission through employee job satisfaction. The research method used is a quantitative research method with descriptive analysis and path analysis. The object of this research is employees who have participated in training and career development at PT Kartika Inti Sejati, with a population of forty-seven respondents. Based on the results of this study it can be concluded that there is an effect of training on employee job satisfaction, career development on employee job satisfaction, and there is an effect of training and career development on employee job satisfaction and while the influence of other remaining factors that are not examined.
\end{abstract}

Keywords: Training, Career Development, Employee Job Satisfaction

\section{INTRODUCTION}

Humans in everyday life are certainly very closely related to matters relating to the organization, both on a small scale to a large scale, meaning that human activities and organizations are closely related to each other, as well as when entering the workforce that a person must have a good interaction within the organization to support that the process of working can run with the existing provisions in the organization.

Competition in business in the modern era like now, in each internal business or better known internally in the company, must have a goal and want to be achieved to the maximum. As in the company, PT Kartika Inti Sejati must have quality employees with good competency specifications, because it is one of the keys to achieving the goals of a company, then job satisfaction of the employees themselves must be improved, because it can give effect to the company can develop or It might even be able to encourage the company to move continuously in the forward step forward and enter into the concept of what the company expects. In Sinambela (2019) a leader must have an effort to increase the work satisfaction of his employees, to build his organization well. Job satisfaction is a reflection of the feelings of an employee towards a responsibility that is being done.

From the description that has been discussed above regarding job satisfaction, when viewed conceptually about job satisfaction, will have an important influence on PT Kartika Inti Sejati because it can achieve its goals quickly. Employees with very high levels of satisfaction have an impact that they will do the job maximally, but if the level of job satisfaction in employees is very low, the impact when doing work will not be maximal.

Those who have a low level of satisfaction in doing their work, this will greatly affect the company's main objectives. To complete the data, here are the issues regarding employee job satisfaction at PT Kartika Inti Sejati: the absence of training opportunities 
following employee interests. And the relationship is not good with supervision. And the absence of promotional opportunities.

Career training and development are one of the important aspects of HR Management at PT Kartika Inti Sejati because the two are very close in their relationships. If PT Kartika Inti Sejati wants to have the advantage of human resources who can have competent competitiveness, therefore a company must be able to have a concept of training and career development on an ongoing basis. According to Mangkunegara (2017), career development is an employee activity that helps employees plan their future careers in the company so that the company and the employees concerned can develop themselves to the maximum.

According to Sinambela (2019) that in general researchers know about several stages of career development, one of which is the exploration stage, if they identify the type of work or position that interests them, then the employee naturally begins to pursue training that is specifically needed.

The purpose of this research is to be able to find out information and data on the Effects of Training and Career Development on Employee Job Satisfaction at PT Kartika Inti Sejati.

\section{METHODS}

The analysis technique in this study is descriptive and verification analysis techniques. This research uses quantitative methods. In this quantitative method, it is used to be able to explain and also describe the facts that have then occurred to the variables to be examined namely Career Training and Development of Employee Job Satisfaction at PT Kartika Inti Sejati.

According to Sugiyono (2019) when viewed in terms of the way or data collection techniques, the data collection techniques can be done by interview (questionnaire), questionnaire (questionnaire), and observation (observation). Data collection using this questionnaire was carried out by distributing it to the employees of PT Kartika Inti Sejati to obtain primary data relating to their responses on Training and Career Development on Employee Job Satisfaction at PT Kartika Inti Sejati.

The population in this study is the number of employees at PT Kartika Inti Sejati as many as 47 people, so in this study the population research, because all employees were made as respondents.

\section{RESULTS AND DISCUSSION Descriptive Analysis}

Training at PT. Kartika Inti Sejati as a whole can be seen in the table below: 
Table 1. Recap of Ideal Scores and Actual Scores of Training Variables

\begin{tabular}{|c|c|c|c|c|}
\hline No & Indicator & $\begin{array}{l}\text { Current } \\
\text { score }\end{array}$ & $\begin{array}{l}\text { Ideal } \\
\text { Score }\end{array}$ & $\begin{array}{l}\text { Percentage } \\
\text { (\%) }\end{array}$ \\
\hline 1 & Improved Performance & 143 & 235 & 60,9 \\
\hline 2 & Improved Work Ethics & 136 & 235 & 57,9 \\
\hline 3 & $\begin{array}{l}\text { Improve employee skills to achieve } \\
\text { maximum performance }\end{array}$ & 144 & 235 & 61,3 \\
\hline 4 & $\begin{array}{l}\text { Improve understanding of work ethics } \\
\text { that must be applied as company } \\
\text { employees }\end{array}$ & 129 & 235 & 54,9 \\
\hline 5 & Work psychology & 138 & 235 & 58,7 \\
\hline 6 & Work communication & 143 & 235 & 60,9 \\
\hline 7 & Discipline & 140 & 235 & 59,6 \\
\hline 8 & Work Ethics & 133 & 235 & 56,6 \\
\hline 9 & Reporting work & 139 & 235 & 59,1 \\
\hline 10 & Exercise in class & 144 & 235 & 61,3 \\
\hline 11 & $\begin{array}{l}\text { Employees who have received } \\
\text { company recommendations }\end{array}$ & 138 & 235 & 58,7 \\
\hline 12 & $\begin{array}{l}\text { Having expertise following training } \\
\text { material }\end{array}$ & 148 & 235 & 63,0 \\
\hline 13 & $\begin{array}{l}\text { Instructors who can generate } \\
\text { motivation }\end{array}$ & 144 & 235 & 61,3 \\
\hline 14 & $\begin{array}{l}\text { The number of training sessions is } 70 \\
\text { sessions or the equivalent of } 52.5 \text { hours }\end{array}$ & 150 & 235 & 63,8 \\
\hline & Total & 1969 & 3290 & 59,8 \\
\hline
\end{tabular}

Source: Questionnaire data processing results (2020)

To see how the training at PT. Kartika Inti Sejati as a whole summed the scores for all respondents' answers about this variable and obtained a total score of 1969. For statements of 14 items, with 47 respondents, an ideal score of $3290(14 \times 47 \times 5)$ was obtained. Therefore, the ideal score percentage obtained is $1969 / 3290 \times 100 \%=59.8 \%$.
The percentage value is in the interval of $52 \%-68 \%$ which is quite a good category. Thus it can be concluded that the training at PT. Kartika Inti Sejati is quite good.

The following is a recap of the actual score along with the ideal score for each indicator in the employee job satisfaction variable: 
Table 2. Recap of Ideal Scores and Actual Scores of Career Development Variables

\begin{tabular}{clccc}
\hline No & \multicolumn{1}{c}{ Indicator } & $\begin{array}{c}\text { Current } \\
\text { score }\end{array}$ & $\begin{array}{c}\text { Ideal } \\
\text { Score }\end{array}$ & $\begin{array}{c}\text { Percentage } \\
(\%)\end{array}$ \\
\hline 1 & $\begin{array}{l}\text { Regulations regarding equal employment } \\
\text { opportunities }\end{array}$ & 140 & 235 & 59,6 \\
2 & $\begin{array}{l}\text { Attention to work quality and personality } \\
3\end{array}$ & 141 & 235 & 60,0 \\
4 & $\begin{array}{l}\text { Education level and job aspirations } \\
\text { Career equity, employees want equal } \\
\text { treatment in a career }\end{array}$ & 138 & 235 & 58,7 \\
5 & $\begin{array}{l}\text { Supervisory concern, Knowledge of career } \\
\text { opportunities in organizations }\end{array}$ & 143 & 235 & 60,0 \\
6 & $\begin{array}{l}\text { Career satisfaction, employees have } \\
\text { different levels of career satisfaction } \\
\text { depending on age and indicators }\end{array}$ & & 235 & 50,9 \\
$\quad \quad$ Total & $\mathbf{8 3 8}$ & $\mathbf{1 4 1 0}$ & $\mathbf{5 9 , 4}$ \\
\hline
\end{tabular}

Source: Questionnaire data processing results (2020)

To see how career development at PT. Kartika Inti Sejati as a whole summed the scores for all respondents' answers about this variable and obtained a total score of 838 . For statements of 6 items, with 47 respondents, an ideal score of 1410 $(6 \times 47 \times 5)$ was obtained. Thus, the ideal score percentage obtained is 838 / $1410 \times 100 \%=59.4 \%$. The percentage value is in the interval of $52 \%-68 \%$ which is quite a good category. Thus it can be concluded that career development at PT. Kartika Inti Sejati is quite good.

The following is a recap of the actual score along with the ideal score for each indicator in the employee job satisfaction variable:

Table 3. Recap of Ideal Scores and Actual Scores of Employee Job Satisfaction Variables

\begin{tabular}{clccc}
\hline No & \multicolumn{1}{c}{ Indicator } & $\begin{array}{c}\text { Current } \\
\text { score }\end{array}$ & $\begin{array}{c}\text { Ideal } \\
\text { Score }\end{array}$ & $\begin{array}{c}\text { Percentage } \\
\text { (\%) }\end{array}$ \\
\hline 1 & $\begin{array}{l}\text { Learning opportunities following interests } \\
\text { and opportunities to be responsible }\end{array}$ & 144 & 235 & 61,3 \\
2 & $\begin{array}{l}\text { The amount of money received by an } \\
\text { employee is in accordance with the } \\
\text { workload and is in balance with other } \\
\text { employees }\end{array}$ & 146 & 235 & 62,1 \\
$3 \quad \begin{array}{l}\text { Promotion based on work performance } \\
\text { achieved by the employee }\end{array}$ & 144 & 235 & 61,3 \\
$4 \quad \begin{array}{l}\text { Supervision by supervisors is motivating } \\
\text { employees }\end{array}$ & 135 & 235 & 57,4 \\
5 & $\begin{array}{l}\text { Support between coworkers } \quad \text { Total } \\
\quad \text { Source: Questinn }\end{array}$ & 149 & 235 & 63,4 \\
& $\quad \mathbf{7 1 8}$ & $\mathbf{1 1 7 5}$ & $\mathbf{6 1 , 1}$ \\
\hline
\end{tabular}

Source: Questionnaire data processing results (2020) 
To see how job satisfaction of employees at PT. Kartika Inti Sejati as a whole summed the scores for all respondents' answers about this variable and obtained a total score of 718. For statements of 5 items, with 47 respondents, an ideal score of 1175 (5x47x5) was obtained. Thus, the ideal score percentage obtained is 718 / $1175 \times 100 \%=61.1 \%$. The percentage value is in the interval of $52 \%-68 \%$ which is a quite satisfying category. Thus it can be concluded that job satisfaction of employees at PT. Kartika Inti Sejati is quite satisfied.

\section{Verification Analysis}

This section will analyze the effect of the Training variable (X1) and Career Development variable (X2) on employee job satisfaction ( $\mathrm{Y})$. To do this analysis the path analysis method is used. The first step is to find the path coefficient to find the effect of the independent variable $(X)$ on the dependent variable (Y). By using SPSS the path coefficient results are obtained as follows:

Table 4. Results of Calculation of Path Coefficient

\section{Coefficients $^{\mathrm{a}}$}

\begin{tabular}{|c|c|c|c|c|c|c|}
\hline \multirow[b]{2}{*}{ Model } & & \multicolumn{2}{|c|}{$\begin{array}{c}\text { Unstandardized } \\
\text { Coefficients }\end{array}$} & \multirow{2}{*}{$\begin{array}{c}\text { Standardized } \\
\text { Coefficients } \\
\text { Beta } \\
\end{array}$} & \multirow[b]{2}{*}{$t$} & \multirow[b]{2}{*}{ Sig. } \\
\hline & & $\mathrm{B}$ & Std. Error & & & \\
\hline \multirow[t]{3}{*}{1} & (Constant) & 2,172 & 845 & & 2,569 &, 014 \\
\hline & $\begin{array}{l}\text { Training (X1) } \\
\text { Career }\end{array}$ & , 169 & ,048 &, 515 & 3,482 &, 001 \\
\hline & Development (X2) & ,299 & 108 & ,411 & 2,778 &, 008 \\
\hline
\end{tabular}

a. Dependent Variable: Employee Job Satisfaction $(Y)$

Source: data processed by the author using SPSS (2020)

After the path coefficient is obtained, then the combined effect of the Training and Career Development variables on Employee Job Satisfaction can be determined from the results of the path coefficient multiplication of the correlation matrix between the $X$

$$
\begin{aligned}
& \mathrm{R}_{\mathrm{Y}(\mathrm{X} 1 \mathrm{X} 2)}^{2}=\left[\begin{array}{cc}
0,515 & 0,411
\end{array}\right] \mathrm{X}\left[\begin{array}{l}
0,885 \\
0,874
\end{array}\right] \\
& =0,815=81,5 \% \\
& \text { Using SPSS, R2Y (X1X2) results } \\
& \text { are obtained as follows: }
\end{aligned}
$$


Table 5. Coefficient of determination

\begin{tabular}{llrrr}
\multicolumn{9}{c}{ Model Summary $^{\text {b }}$} \\
\hline Model & R & R Square & $\begin{array}{c}\text { Adjusted R } \\
\text { Square }\end{array}$ & $\begin{array}{c}\text { Std. Error of } \\
\text { the Estimate }\end{array}$ \\
\hline 1 &, $903^{\mathrm{a}}$ &, 815 &, 807 & 1,62028 \\
\hline
\end{tabular}

a. Predictors: (Constant), Career Development (X2),

Training (X1)

b. Dependent Variable: Employee Job Satisfaction (Y)

Source: data processed by the author using SPSS (2020)

From the above calculation, it is known that the joint effect of the two independent variables on Employee Job Satisfaction is $81.5 \%$, while the magnitude of the influence of other variables not observed is $100 \%-81.5 \%$ $=18.5 \%$.
To see more about the direct and indirect effects of each independent variable on the dependent variable, the following are the results of the calculation of direct and indirect effects.

Table 6. Direct and indirect effects of Training and Career Development on Employee Job Satisfaction

\begin{tabular}{ccccccc}
\hline Variable & $\begin{array}{c}\text { Path } \\
\text { coefficient }\end{array}$ & $\begin{array}{c}\text { Direct } \\
\text { Influence } \\
(\%)\end{array}$ & \multicolumn{2}{c}{$\begin{array}{c}\text { Indirect influence } \\
\text { (through), in (\%) } \\
\mathbf{X} \text { 1 }\end{array}$} & $\begin{array}{c}\text { Total Indirect } \\
\text { Influence (\%) }\end{array}$ & $\begin{array}{c}\text { Total } \\
\text { Influence } \\
(\%)\end{array}$ \\
\hline X1 & 0,515 & 26,6 & - & 19,0 & 19,0 & 45,6 \\
X2 & 0,411 & 16,9 & 19,0 & - & 19,0 & 35,9 \\
& \multicolumn{7}{c}{ Total Influence } \\
\hline
\end{tabular}

Source: data processed by the author using SPSS (2020)

From the table above it can be seen that the Direct Effect of Training (X1) on Employee Job Satisfaction is $26.6 \%$ and the indirect effect through Career Development variables is $19 \%$ so that the total effect of Training (X1) on Employee Job Satisfaction is $45.6 \%$. While the direct influence of Career Development (X2) on Employee Job Satisfaction was $16.9 \%$ and the indirect effect through the Training variable was $19 \%$ so that the total influence of Career Development (X2) on Employee Job Satisfaction was $35.9 \%$.

Based on the calculation above, it can be seen that the Training variable has an effect on Employee Job Satisfaction of $45.6 \%$, and the effect given by the Career Development variable is $35.9 \%$, and the influence of both is significant. The effect of $\mathrm{XI}$ and $\mathrm{X} 2$ on $\mathrm{Y}$ was $81.5 \%$, and the remaining $18.5 \%$ was influenced by variables not examined. This research is in line with the results of Rosmadi's research (2018) training and career development have a significant relationship and according to Irwanto (2017), The Effect of Training on Employee Job Satisfaction has a very significant influence. And According to Kurniawan (2015) career development has a significant and simultaneous effect on employee job satisfaction. This means increasing employee career development then employees will have high job satisfaction.

\section{CONCLUSION}

The training at PT Katika Inti Sejati was good enough, but there were some 
things that could be said to be lacking in this training, namely: improving work ethics, increasing understanding of work ethics that must be applied as company employees, work psychology, work ethics and employees who have received a company recommendation. In addition, Career Development at PT Kartika Inti Sejati is also quite good, but there are still a number of things that can be said to be lacking in career development, namely: regulations regarding equal employment opportunities, education levels and job aspirations, employees have satisfaction levels different careers depending on age and indicators (career satisfaction).

Employee Job Satisfaction at PT Kartika Inti Sejati is quite satisfied, but there are still a number of things that can be said to be lacking in this employee job satisfaction, namely: learning opportunities in accordance with interests and responsibilities, promotions based on work performance achieved by the employee, supervisory supervision is motivating employees.

\section{REFERENCES}

Irwanto, Felicia Deasy. (2017). Pengaruh Tenaga Pendidikan Pelatihan, Motivasi dan Kompensasi Terhadap Kepuasan Kerja Tenaga Kependidikan Kampus. Jurnal Magister Manajemen. 3(1).

Kurniawan, Kenny Yulianto. (2015). Pengaruh Pengembangan Karier Dan Kompensasi Terhadap Kepuasan Kerja Karyawan di PT Parit Padang Global. Jurnal AGORA, 3(2).

Mangkunegara, Anwar Prabu (2017). Manajemen Sumber Daya Manusia Perusahaan. Bandung: Rosada.

Rosmadi, Maskarto Lucky Nara. (2018). Pengaruh Pelatihan, Disiplin, Dan Pengembangan Karier Terhadap Kinerja Karyawan Outsourching PT Garda Utama. Jurnal Manajemen Dan Informatika, 14(3).

Sinambela, Lijan Poltak. (2019). Manajemen Sumber Daya Manusia. Jakarta: Bumi Aksara.

Sugiyono. (2019). Metode penelitian kuantitatif, kualitatif dan $R \& D$. Bandung: Alfabeta. 